\title{
Situational Analysis of Vietnam for Belt and Road Initiative
}

\author{
Doan Ba Toai ${ }^{1, a}$, Xi Guan ${ }^{1, b,{ }^{*}}$, Amogh Ghimire ${ }^{1, c}$ \\ College of Economics, Fujian Agriculture and Forestry University, Fuzhou 350002, China \\ a2220369435@qq.com, b10523445@qq.com, camoghimire@yahoo.com
}

*Corresponding author: Xi Guan, College of Economics, Fujian Agriculture and Forestry University, Fuzhou 350002,

Keywords: SWOT Analysis, Belt and Road Initiative, Vietnam, Project.

\begin{abstract}
This paper is motivated to investigate the situational analysis of Vietnam in the implementation of the Belt and Road Initiative (BRI) of China. The bilateral relation between Vietnam and China and Vietnam's perspective towards OBOR project were discussed in specific in order to address the impacts of BRI and the role of Vietnam in this ambitious project of China. To more important, a SWOT analysis is taken as portrayed to explore strengths, weaknesses, opportunities, and threats of Vietnam under the context of The Belt and Road Initiative. The Result, we found that Vietnam can receive numerous benefits from the BRI Project.
\end{abstract}

\section{Introduction}

The Belt and Road Initiative (BRI) has been well-known as One Belt, One Road (OBOR) project and it was proposed in 2013 by Chinese President Xi Jinping with the purpose to foster regional cooperation and connectivity on a transcontinental scale. By combining of the Maritime Silk Road and Silk Road Economic Belt, China's BRI is a development strategic project which is made up of shipping lanes and overland corridors. In reality, trillions of dollars are used for infrastructure and international trade investments. From a standpoint of view, it is agreed that the Belt and Road Initiative can connect the people over the world and facilitates various opportunities for global peace and this ambitious project might help China strengthen trading and investment activities with more than sixty countries throughout Asia, Middle East and Europe [1]. Beijing's economic leadership and political leverage over neighboring regions may receive a number of benefits through the initiative of jointly building the OBOR. To an extent, it can be said that China is hungry to play an expanding role on the global platform and the nation is willing to spend massive amounts of capital in the process.

In particular, the BRI or the OBOR of China has certain influences toward Vietnam. Vietnam has a playing role in this project and hence it is believed that the nation would be impacted significantly by instability if these network roads get damaged. As for following, this paper aims to make an attempt to investigate different perspectives relating to the Belt and Road Initiative. To more specific, bilateral relation between Vietnam and China, as well as an evaluation of strengths, weaknesses, opportunities, and threats of Vietnam under the OBOR project will be explored in this paper.

\section{Glance of Vietnam}

First and foremost, Vietnam has a strategic location has the nation is located in the center of ASEAN. Based on the nation's economic models, Vietnam can be considered as one of the most dynamic markets in the world. The Vietnamese government established open and market-oriented trade policy with the purpose to attract foreign investments to strengthen economic growth of the country. Generally speaking, Vietnam is at a cross-road and thanks for both foreign and domestic investment the national exports have gained positive market share on the global landscape. In 2018, The World Bank also make remark about Vietnam that, it is such a remarkable development in Vietnam's economy as the nation has turned to be a lower middle-income economy from one of the 
world's poorest countries [2]. In order to alter the country to become a more industrial market from an agrarian economy to a government's Doi Moi policy has played a crucial role since 1986. In regards, throughout the past three decades the economic liberalization, economic growth, and development of Vietnam have never stopped spurring [3].

Currently, the country experiences rapid changes in demographic profile and social culture. Estimated in 2017, Vietnam's population reached about 95 million and this number will increase continually in the upcoming years. To more important, the nation's population is considered as an aging population as the number of older people is increasing while the birthrate has dropped. Because of it, Vietnam is preparing supports for aging population [4]. In 2018, Business Times state that, the purpose to continue on a strong GDP growth, the country ought to work to raise its labor productivity within sectors to achieve an economy-wide boost and country also recorded the Gross Domestic Product (GDP) rate in a decade [5]. The nation's GDP Growth Rate from 2000 to 2018 recorded 6.25 percent [6]. To an extent, due to the fast developing economy in Southeast Asia, Vietnam is now being listed as an attractive destination for foreign investments.

\section{Bilateral relation between Vietnam and China}

Once talking about the relation between Vietnam and China, the conflict over sovereignty in the South China Sea is a controversial topic. Indeed, it is a tough tension between two countries although Vietnam and China generally have close relations. In a comparison, there is a big difference in the naval power between these two countries and thus problems arisen from the South China Sea dispute may put Vietnam into a risky and complex position. Until the present time, the tackling of conflicts over the South China Sea dispute has no evident progress. In relation with it, a number of multinational energy companies are entangled in the offshore dispute.

Aside from tumult and hostility, both nations have maintained a collaborative relationship for a long time. From a standpoint point of view, Vietnam and China have comparable political systems and both countries are trying to balance continued economic reform. Improvements in relations between Vietnam and China have been driven primarily by shared domestic challenges and one of the key factors that can enhance a better relationship between these two countries is economics, with increasing trade and investment. Obviously, it can be said that both nations are now becoming more interdependent in their bilateral relations. Nevertheless, it should be noticed that the discrepancy in the trade balance is an apparent issue. The record for Vietnam's trade deficit with China is an increasing number as Vietnam accounts for less than one percent of China's total export trade. During 2011, McCornac found that, the mainland is one of the most important and largest partners of Vietnam and although there are some positive signs in the relations between China and Vietnam, yet whenever China swings the tightrope, Vietnam finds itself in a more precarious and unsafe position [7].

\section{Vietnam's perspective towards OBOR}

When examining BRI or OBOR opportunities, The BRI is an important source of funding that Vietnam may want to tap to finance its infrastructure projects. To an extent, it is found that the demand for infrastructure investments in Vietnam is going to increase in the next few years. However, the nation would not be able to meet the need for development due to a lower official development assistance inflow, barriers in the boost of Public Private Partnership projects and limited funded investment from the state. As a result, Vietnam joined the BRI project and signed the Memorandum of Understanding (MOU) in 2017. Vietnam welcomed the closer economic and logistics ties outlined as part of the BRI proposal with efforts to promote economic and regional connectivity.

From another point of view, many economists stated that Vietnam is offering diplomatic support to China's Belt and Road Initiative, Vietnam may be seen as a crucial part of the maritime component of China's ambitious BRI. Nevertheless, Vietnam ought to be cautious about applying for loans from BRI projects. To achieve sustainability and effectiveness in project implementation, 
the principles of consensus, equality, voluntariness, transparency, openness, mutual respect and benefits, and compliance with the UN Charter and international law must be ensured between Vietnam and China. The view of Vietnam relating to China's ambitious project will be dependent on the commercial terms of BRI loans and the credibility of Chinese contractors. Therefore, in order to ensure the BRI's long-term success in Vietnam and in other countries generally, the performance of the first batch of BRI projects should meet the expectations of not only the beneficiary countries but also of the international community [8]. Especially, as part of the BRI Vietnamese business communities have an upbeat attitude over the prospects of the country. Positive trade prospects in the long term could be expected by both parties. Notwithstanding the foregoing, Vietnam is still waiting for the outcome of the first batch of BRI projects before making any further decisions, although some other countries in the region are now looking for significant benefits from working with China [9].

\section{SWOT analysis of Vietnam for OBOR}

Table 1. SWOT analysis of Vietnam for OBOR

\begin{tabular}{cc}
\hline Strengths & Weaknesses \\
\hline Being a door gate to South East Asia & Weak military power \\
Rich and untapped natural resources & Lack of construction funds \\
Cheap labor cost & Slow industrial development. \\
Young workforce & Trade imbalance \\
\hline Opportunities & Threats \\
\hline Infrastructure building & Geopolitical security risks \\
Foreign investments & Environmental issues \\
Economic developments & \\
Urbanization & \\
\hline
\end{tabular}

\subsection{Strengths}

First of all, Vietnam is a door gate to South East Asia region and that allows the country play an essential role in in transporting goods produced in the Chinese mainland while opening the domestic market to external suppliers. In addition, Vietnam has rich natural resources that their true potential is not fully tapped. As a country considered rich in minerals, Vietnam has the potential to emulate this success and use investment in the mining industry to bring foreign direct investment (FDI) that can generate more employment opportunities, infrastructural development or services, and economic stability to many less developed mountainous provinces in the country. Nonetheless, relating to the exploitation of the natural resource, Vietnam has to look at its neighboring countries like China and Laos, which share very similar geology, have been able to find and develop significant copper, nickel, tin, and gold mining projects to an internationally accepted standard. By comparison, Vietnam only has one modest copper mine and several small scale gold operations.

To add on, low wage labor cost can be listed as a strength of Vietnam as that factor helps the country attract more investors. In fact, there are 54.5 million people in the nation's labor force and the majority of the labor forces are young workers. Also, 74\% of the labor force is under 50 years of age. Under this context, foreign investors who are investing in Vietnam can think for long term projects. A young and inexpensive labor force is one of the biggest advantages in the period of the economic development of Vietnam.

\subsection{Weaknesses}

Vietnam is a close neighbor of the mainland and Vietnam is fearful just by the military power of the main land. Over the past two decades, Vietnam has put efforts to strengthen some of its aerial and maritime capabilities, however, lack of renewal in the military equipment is such a big weakness of Vietnam. In 2017, Wu sta obsolescence can be tackled by increasing the budget for military equipment, yet that would lead to another problem in the balance between defense and other needs [10]. To an extent, Vietnam is not poor in resources, however, the country lacks of funds for the 
national development. In a certain case of infrastructure system, the construction on the six-line railway was first proposed during 2001. Nevertheless, the project has been delayed due to insufficient funds for the state [11].

On the other side regarding the cross-border trade, Vietnam imports much more from China and so a continual increase in the trade deficit Vietnam with China has led to a significant imbalance in trade between two nations. That issue may have a negative impact on the balance of payments and the nation's macroeconomic might be threatened in consequence [12]. Vietnam and China have established a comprehensive strategic partnership and implemented dozens of cooperative mechanisms at all levels in all areas. However, it seems like Vietnam is lagged in levels of industrial development. In this sense, by supporting an ambition to fill in the missing piece of the connectivity puzzle of China, Vietnam can receive beneficiary of Chinese investments which mainly focus on manufacturing, electricity, construction and mining industries. By joining the BRI project, the nation will have more chances to approach expertise and access the resources. Also, Vietnam can receive financial support to meet the need for infrastructural development. Nonetheless, there are many potential risks and challenges that Vietnam ought to watch closely when received investments or funds from the advanced country.

\subsection{Opportunities}

Being involved in the BRI with China, Vietnam can receive numerous benefits from the promotion of capital and technological investment into ports, transport routes, and other infrastructure. As a result, the nation will be able to tap into new resources, enhance its resource distribution and market integration. With improving roads, ports, airports, and seaports, manufacturers can get their goods in and out of Vietnam more easily, which then allows Vietnam to approach a better facilitation of trade and investment with other foreign countries. From the advantage perspective, new opportunities for multinationals investing in Vietnam can be expected as when the Vietnamese infrastructure is improved, it will increase trade flow and volume which ultimately give further impetus to economic integration between Vietnam and other countries.

Also, joining the OBOR project may be the way to build a mutually beneficial strategic relationship with China. Since the BRI fosters connectivity within countries, Vietnam and many other countries can receive benefits from interconnected transport systems and enjoy production booms along the Belt and Road route. In particular case of Vietnam, the route will mark a milestone in boosting exchanges and economic cooperation between Vietnam and the mainland. Especially, China's BRI project may create more working opportunities for constructions crews and employees in the trade-related industry in Vietnam. Furthermore, as a part of the Belt and Road Initiative Vietnam will be able to improve the practical experience and learn from the cooperation with China [13]. To more important, China has been the largest trade partner of Vietnam for years, thus Vietnam expects the expansion of trade opportunities from joining the One Belt, One Road project, while also aligning it with Vietnam's Two Corridors and One Circle plan. As a result, a stronger socioeconomic development can be expected as an opportunity from the joining of BRI.

\subsection{Threats}

\subsubsection{Geopolitical and security risks}

From a certain point of view, the BRI may be a genuinely puzzling program. Vietnam demands for infrastructural development, yet lack of fund and budget from the state. Meanwhile, the mainland has capital, experience and capability for infrastructure investment and the BRI project of China can help strengthen the mainland's position in the region. In a long run, the old regional order could be eroded. Geopolitical problems may arise and that will barrier the approaching of international policy. Strongly agreed, the opportunities that the B\&R initiative brings also result in some risks and challenges in return. The BRI covers shipping and land routes through various countries and thence political, credit, and security risks cannot be inevitable at all. Furthermore, increasing trade and economic connections implies a greater demand for complex financial services, such as cash flow management, foreign exchange, cross-border payments or risk and liability management. In 2017, Simigh quoted, increasing vulnerability could be generated from geographical connectivity, 
as well as the implementation of the BRI project also provides more opportunities for human, drug and arms trafficking. Against this background, it is important to eliminate potential security problems in order to avoid a rise in transactional costs from the belt and road initiatives [14].

\subsubsection{Environmental degradation}

The challenges potentially brought about by the initiative should be aware by the Vietnamese government. In fact, negative impacts of China's BRI on the surrounding physical environment have been investigating by many scientists and environmentalists. For instance, the ambitious project of China promotes infrastructure building at a large scale and if those activities are not carefully handled by parties, permanent environmental damages are apparent. In addition, extensive infrastructure investment can result in pollution, the spread of invasive species, restrictions on animal movements, habitat loss, and wildlife mortality that will change the ecosystem in consequence. According to Sok finding in 2017, it was found that, asserted the forest, wildlife, and physical environment could be threatened by construction activities under China's BRI project. Indeed, the BRI road building presents significant development opportunities, yet it may also bring substantial risks for people and Vietnam's natural capital, including forests, rivers, land, biodiversity, and oceans [15].

\section{Conclusion}

To sum up, there are many benefits could be shared among countries who are and willing to be part of One Belt One Road initiative, and the inherent risks will not obstacle the progress of world infrastructure upgrading if they are properly managed by parties. In fact, negative and positive sides can arise alongside each other in every single strategy, including China's BRI but Vietnam must try to ensure to yield positive results. In a recommendation, project risk assessment and supervision skills would be in high demand and through better planning and design these risks can be avoided and mitigated in a positive manner. Under the BRI, China has a series of arrangements and agreements with its Asian neighbors, including Vietnam as the BRI is expected to alter the regional economic landscape by further enhancing development and connectivity in the future.

\section{Acknowledgement}

This paper was financially supported by the Collaborative Innovation of Chinese Oolong Tea Industry-Collaborative Innovation Center (2011) of Fujian Province.

\section{References}

[1] Sarker, M.I. Hossin,A. Yin, X. and Sarkar, K. One Belt One Road Initiative of China: Implication for Future of Global Development, Modern Economy, vol. 9, pp. 623-638, 2018.

[2] The World Bank, Vietnam Overview. Available at: http://www.worldbank.org/en/country/vietnam/overview (Last accessed: 02 Aug 2018), 2018.

[3] Index of Economic Freedom Vietnam. Available at: https://www.heritage.org/index/country/vietnam (Last accessed: 02 Aug 2018), 2018.

[4] Vietnam News (2017) Vietnam prepares to support aging population. Available at: https://vietnamnews.vn/society/health/393500/viet-nam-prepares-to-support-aging-population.ht ml (Last accessed: 02 Aug 2018), 2018.

[5] The Business Times, Vietnam's economy expands 7.38\%, best rate in a decade. Available at: https://www.businesstimes.com.sg/government-economy/vietnams-economy-expands-738-bestrate-in-a-decade (Last accessed: 02 Aug 2018), 2018.

[6] Trading Economic, Vietnam GDP Growth Rate. Available at: https://tradingeconomics.com/vietnam/gdp-growth (Last accessed: 02 Aug 2018), 2018. 
[7] McCornac, D.C.,Vietnam's Relations with China: A Delicate Balancing Act. Available at https://www.chinacenter.net/2011/china_currents/10-2/vietnams-relations-with-china-a-delicate -balancing-act/ (Last accessed: 02 Aug 2018), 2018.

[8] Le, H.H. The Belt and Road Initiative in Vietnam: Challenges and Prospects, ISEAS - Yusof Ishak Institute, vol. 18, pp. 1-7, 2018.

[9] Shean, W.T.K., Challenges for the Belt and Road Initiative in Vietnam. Available at: https://theaseanpost.com/article/challenges-belt-and-road-initiative-vietnam (Last accessed: 02 Aug 2018), 2018.

[10] Wu, S.S., The Weak Points in Vietnam's Miliary. Available at: https://thediplomat.com/2017/06/the-weak-points-in-vietnams-miliary/ (Last accessed: 02 Aug 2018), 2017.

[11]Hutt, D., Insufficient funds in Vietnam. Available at: http://www.atimes.com/article/insufficient-funds-vietnam/ (Last accessed: 02 Aug 2018), 2017.

[12]Vietnamnet, Vietnam's trade deficit increases day by day. Available at: http://english.vietnamnet.vn/fms/business/177475/vietnam-s-trade-deficit-increases-day-by-day .html (Last accessed: 02 Aug 2018), 2017.

[13]Xinhua, Interview: Belt and Road Initiative to benefit Vietnam: expert. Available at: http://www.xinhuanet.com/english/2017-06/12/c_136360172.htm (Last accessed: 02 Aug 2018), 2017.

[14]Simigh, F., Security Challenges of One Belt One Road Initiative. Available at: http://beltandroadcenter.org/2017/11/07/security-challenges-of-one-belt-one-road-initiative/ (Last accessed: 02 Aug 2018), 2017.

[15]Sok, S., Pros and cons of China's Belt and Road plan. Available at:https://www.khmertimeskh.com/news/39680/pros-and-cons-of-china---s-belt-and-road-plan/ (Last accessed: 02 Aug 2018), 2017. 